\title{
Pengaruh Ukuran Perusahaan, Leverage, dan Profitabilitas Pada CSR Disclosure
}

\author{
Ni Komang Ayu Trisna Dewi ${ }^{1}$ \\ Maria Mediatrix Ratna Sari ${ }^{2}$ \\ ${ }^{1,2}$ Fakultas Ekonomi dan Bisnis Universitas Udayana (Unud), Bali, Indonesia \\ e-mail: ayutrisnadewikomang@gmail.com
}

\begin{abstract}
ABSTRAK
Penelitian ini bertujuan untuk mengetahui pengaruh ukuran perusahaan, leverage, dan profitabilitas pada CSR disclosure. Teori yang digunakan dalam penelitian ini adalah teori stakeholder dan teori legitimasi. Sampel penelitian sebanyak 29 perusahaan manufaktur yang terdaftar di Bursa Efek Indonesia (BEI) periode 2015-2017 dengan metode purposive sampling. Teknik analisis yang digunakan adalah Analisis Regresi Linier Berganda. Hasil penelitian menunjukkan bahwa (1) ukuran perusahaan berpengaruh positif pada pengungkapan CSR yang menunjukkan bahwa semakin besar ukuran perusahaan, maka kebijakan pengungkapan CSR akan semakin meluas., (2) leverage tidak berpengaruh pada pengungkapan CSR yang menunjukkan bahwa rasio leverage suatu perusahaan tidak mempengaruhi pengungkapan CSR, (3) Profitabilitas menunjukkan bahwa semakin besar proftabilitas perusahaan maka perusahaan berkewajiban untuk mengungkapkan CSR
\end{abstract}

Kata Kunci: CSR, ukuran perusahaan, leverage, profitabilitas

\begin{abstract}
This study aims to determine the effect of company size, leverage, and profitability on CSR disclosure. The theory used in this study is stakeholder theory and legitimacy theory. The research sample was 29 manufacturing companies listed on the Indonesia Stock Exchange (IDX) for the period 2015-2017 with a purposive sampling method. The analysis technique used is the Analysis of Multiple Linear Regression. The results showed that (1) the size of the company has a positive effect on CSR disclosure which shows that the greater the size of the company, the CSR disclosure policy will be more widespread. (2) leverage does not affect CSR disclosure which shows that a company's leverage ratio does not affect disclosure CSR, (3) Profitability shows that the greater the company's profitability, the company is obliged to disclose CSR

Keywords: CSR, company size, leverage, profitability
\end{abstract}

\section{PENDAHULUAN}

Modernisasi suatu wilayah sering kali didukung oleh keberadaan pabrik, perusahaan atau industri yang beroperasi aktif pada wilayah tersebut. Perusahaan atau industri yang aktif menjalankan kegiatan operasionalnya kerap kali menghadapi masalah-masalah internal maupun eksternal. Masalah internal perusahaan menyangkut dengan perhatian kesejahteraan, kesehatan dan 
Ni Komang Ayu Trisna Dewi dan Maria Mediatrix Ratna Sari. Pengaruh ...

keselamatan kerja karyawan, sedangkan masalah eksternal perusahaan menyangkut dengan masyarakat umum serta penanganan lingkungan di sekitar perusahaan (Rofiqkoh \& Priyadi, 2016)

Beberapa tahun terakhir tanggungjawab sosial perusahaan telah menjadi isu perkembangan utama perusahaan. Dalam menjalankan usahanya, perusahaan tidak terlepas dari lingkungan dan masyarakat. (Braendle \& Mozghovyi, 2013)menyatakan bahwa pada hakikatnya setiap manusia maupun organisasi memiliki tanggung jawab sosial tanggung jawab sosial terhadap lingkungan. Salah satu informasi yang perlu diungkapkan demi keberlangsungan perusahaan adalah informasi tentang tanggungjawab sosial perusahaan. Tanggungjawab sosial perusahaan merupakan salah satu kewajiban yang harus dilaksanakan oleh suatu perusahaan dimana merupakan wujud tanggungjawab dan sikap kepedulian perusahaan terhadap lingkungan dan masyarakat.

Lingkungan sekitar perusahaan tentu erat sekali kaitannya dengan bagaimana perusahaan mampu meminimalisir masalah-masalah yang terjadi pada masyarakat akibat aktivitas yang dijalankannya. Perusahaan yang memahami bahwa tanggung jawab mereka bukan hanya memberikan kesempatan kerja bagi masyarakat serta menghasilkan produk-produk yang berkualitas dan terjangkau, akan tetapi lebih luas lagi perusahaan dapat memberikan manfaat bagi lingkungan di sekitarnya sehingga secara tidak langsung suatu saat nanti perusahaan akan mendapatkan manfaat atas kepeduliannya terhadap lingkungan. Pemerintah juga telah mengeluarkan aturan bahwa setiap perusahaan (penanam modal) berkewajiban untuk melaksanakan tanggung jawab sosial perusahaan (Pasal 74 
UU Perseroan Terbatas No.40/(DPR, 2007)). Akan tetapi tidak semua perusahaan mengungkapkan tentang aktivitas sosialnya di dalam laporan tahunan. Hal ini dikarenakan jenis pengungkapannya masih bersifat sukarela (voluntary disclosure). Sebagaimana tertulis dalam Pernyataan Standar Akuntansi Keuangan (PSAK) No 1 (revisi per 1 Juli 2009) paragraf kesembilan: "Perusahaan dapat pula menyajikan laporan tambahan seperti laporan mengenai lingkungan hidup dan laporan nilai tambah (value added statement) khususnya bagi industri dimana faktor-faktor lingkungan hidup memegang peranan penting dan bagi industri yang menganggap pegawai sebagai kelompok pengguna laporan yang memegang peranan penting”.

(Riandi, Hasan, \& Siregar, 2010) Di Indonesia sudah banyak berbagai kasus kerusakan lingkungan seperti, PT Lapindo Brantas di Kabupaten Sidoarjo adalah peristiwa menyemburnya lumpur panas di lokasi pengeboran Lapindo Brantas di Dusun Balongnongo Desa Renokenongo, Kecamatan Porong, Kabupaten Sidoarjo Jawa Timur. Penyemburan lumpur tersebut menyebabkan tergenangnya kawasan permukiman warga, lahan pertanian, dan perindustrian di tiga kecamatan di sekitarnya, serta memengaruhi aktivitas perekonomian di Jawa Timur. PT. Newmont Minahasa Raya yang telah melakukan pencemaran lingkungan di Teluk Buyat dengan membuang limbah di perairan teluk Buyat, dampak yang terjadi dirasakan oleh masyarakat sekitar seperti sakit kepala, batuk, beringus, demam, gangguan daya ingat, sakit perut, sakit maag, sesak napas, gatal-gatal dan lain-lain hingga ditemukannya puluhan bangkai ikan mati mengapung dan terdampar di pesisir pantai. Hal tersebut merupakan bukti 
kongkrit bahwa setiap perusahaan yang melakukan aktivitas produksi dengan memanfaatkan sumber daya alam, cenderung membawa dampak terjadinya kerusakan lingkungan. Dari sektor industri sendiri juga ada beberapa kasus pencemaran lingkungan seperti, PT Industri Gula Glenmore mencemari Sungai Glenmore yang mengalir ke pesisir selatan Banyuwangi, Jawa Timur yang menyebabkan ribuan ikan mati dan gatal-gatal pada warga. Selain itu ada juga perusahaan tekstil yang melakukan pencemaran lingkungan antara lain PT. KHTII, PT. ISIT dan PT. FST. Pelaku industri tekstil di Kecamatan Rancaelek, Kabupaten Bandung, Jawa Barat ini terbukti sengaja membuang limbah sehingga menyebabkan pencemaran lingkungan di sekitar lokasi. Perkiraan luas lahan tercemar di Kecamatan Rancaekek seluas 752 ha dari total luas lahan baku sawah 983 ha. (www.kompasiana, 2018)

Dengan banyaknya kasus tersebut, merupakan bukti rendahnya perhatian perusahaan terhadap dampak lingkungan dari aktivitas industrinya. Berbagai macam kasus kerusakan lingkungan tersebut, diperlukan kebijakan responsif dari perusahaan agar dapat menekan terjadinya pencemaran lingkungan, dengan mematuhi kebijakan-kebijakan yang telah di tetapkan oleh pemerintah atau kementerian sesuai dengan norma-norma yang berlaku dan tidak bertindak egois dengan hanya mementingkan keuntungan perusahaan sendiri saja, tetapi juga harus memperhatikan dampak sosial dan lingkungan masyarakat sekitar aktivitas operasional perusahaan.

Dalam proses produksinya perusahaan manufaktur mau tidak mau akan menghasilkan limbah produksi, sangat erat hubungannya dengan masalah 
pencemaran lingkungan. Proses produksi yang dilakukan juga mengharuskannya untuk memiliki tenaga kerja bagian produksi sehingga masalah keselamatan kerja juga harus diperhatikan. Di sisi lain perusahaan manufaktur adalah perusahaan yang menjual produk kepada konsumen sehingga isu keselamatan dan keamanan produk menjadi penting untuk diungkapkan kepada konsumen sehingga isu keselamatan dan keamanan produk menjadi penting untuk diungkapkan kepada masyarakat. Oleh karena itu dengan banyaknya masalah-masalah yang terjadi, sangat diharapkan agar setiap perusahaan lebih meningkatkan kesadaran akan tanggung jawab sosialnya dengan cara memperhatikan dan mempertimbangkan akibat dari kegiatan operasional yang dilakukannya.

Ilmu akuntansi bukan hanya merangkum informasi tentang hubungan perusahaan dengan pihak ketiga, tetapi juga dengan lingkungannya Pencemaran lingkungan yang terjadi pada setiap perusahaan merupakan kasus yang menimbulkan dampak negatif bagi masyararakat, sehingga dengan banyaknya kasus pencemaran lingkungan yang sangat penting untuk diperhatikan berkembanglah ilmu akuntansi mengenai yang selama ini hanya memberikan informasi tentang pengungkapan informasi kegiatan perusahaan. Tanggungjawab sosial atau Corporate Social Responsibility yang selanjutnya akan disingkat dengan CSR, muncul akibat adanya modernisasi masyarakat yang sudah memahami bahwa aktivitas yang dilakukan oleh perusahaan dapat membawa dampak negatif pada lingkungannya. Apalagi hal ini sangat dekat sekali dengan aktivitas yang dilakukan oleh perusahaan manufaktur karena perusahaan 
Ni Komang Ayu Trisna Dewi dan Maria Mediatrix Ratna Sari. Pengaruh ...

manufaktur adalah perusahaan yang paling banyak berinteraksi dengan masyarakat.

Dibandingkan dengan perusahan low profile, perusahaan high profile jauh lebih memperhatikan dan mengutamakan pengungkapan sosial. Ukuran perusahaan dapat dikatakan sangat mempengaruhi terlaksananya pengungkapan sosial, hal itu dikarenakan dengan semakin besarnya ukuran perusahaan maka tanggungjawab perusahaan juga akan berpengaruh pada pengungkapan yang harus dilakukan. Suripto dan Zaki (1999) menyatakan bahwa dengan besarnya ukuran perusahaan, hal itu akan berpengaruh pada banyaknya karyawan, penggunaan sistem yang lebih canggih, besarnya laba yang diperoleh, produksi barang yang banyak, serta luasnya area lingkungan masyarakat yang dipergunakan, sehingga banyak pihak yang harus mendapatkan haknya yaitu adanya pengugkapan yang transparan dari perusahaan. Adanya dampak dari aktivitas perusahaan telah menyadarkan bahwa kerusakan lingkungan yang terjadi bisa dikurangi agar dapat dimanfaatkan oleh generasi mendatang (Oktariani, 2014)

Penelitian mengenai variabel ukuran perusahaan yang dilakukan oleh (Andriani, Fakultas, 2011) adalah positif secara parsial. Penelitian (Gusti Ayu Dyah Indraswari, 2014), (Purba, 2015) serta (Yanti \& Budiasih, 2016) menemukan bahwa ukuran perusahaan berpengaruh terhadap CSR disclosure. Sedangkan (Pradnyani \& Sisdyani, 2015) menemukan bahwa ukuran perusahaan tidak mempengaruhi pengungkapan tanggung jawab sosial perusahaan yang mencerminkan bahwa klasifikasi besaran perusahaan tidak mempengaruhi luas pengungkapan tanggung jawab sosial perusahaan. 
Leverage merupakan pengukur besarnya aktiva yang dibiayai dengan hutang. Hutang yang digunakan untuk membiayai aktiva berasal dari kreditor, bukan dari pemegang saham ataupun investor. (Oktariani, 2014) menyatakan perusahaan dengan rasio leverage yang lebih tinggi akan mengungkapkan lebih banyak informasi, karena biaya keagenan perusahaan dengan struktur modal seperti itu lebih tinggi. Tambahan informasi diperlukan untuk menghilangkan keraguan pemegang obligasi terhadap dipenuhinya hak-hak mereka sebagai kreditur. Oleh karena itu perusahaan dengan rasio leverage yang tinggi memiliki kewajiban untuk melakukan ungkapan yang lebih luas dari pada perusahaan dengan rasio leverage yang rendah. Hasil penelitian yang dilakukan oleh (Purba, 2015), (Yanti \& Budiasih, 2016) dan (Rofiqkoh \& Priyadi, 2016) menemukan bahwa variabel leverage berpengaruh positif terhadap pengungkapan tanggung jawab sosial perusahaan. Sedangkan (Pradnyani \& Sisdyani, 2015) serta (Wulandari \& Sudana, 2018) menemukan bahwa leverage tidak mempengaruhi pengungkapan tanggung jawab sosial perusahaan.

Profitabilitas merupakan faktor yang membuat manajemen menjadi bebas dan fleksibel untuk mengungkapkan pertanggungjawaban sosial kepada pemegang saham. Profitabilitas merupakan suatu indikator kinerja yang dilakukan manajemen dalam mengelola kekayaan perusahaan yang ditunjukkan oleh laba yang dihasilkan. Secara garisbesar, laba yang dihasilkan perusahaan berasal dari penjualan dan investasi yang dilakukan perusahaan. Secara umum, dalam menjabarkan penjualan menjadi laba menunjukan prestosi profitabilitas perusahaan. Maka salah satu tujuan perusahaan yaitu mencapai keuntungan yang 
Ni Komang Ayu Trisna Dewi dan Maria Mediatrix Ratna Sari. Pengaruh ...

nantinya akan dapat meningkatkan kesejahteraan para pemegang saham (Milne \& Hackston, 1996) Beberapa penelitian sebelumnya seperti penelitian oleh (Pradnyani \& Sisdyani, 2015) (Yanti \& Budiasih, 2016) dan (Gusti Ayu Dyah Indraswari, 2014)yang menyatakan bahwa profitabilitas memiliki pengaruh signifikan pada pengungkapan CSR. Pendapat lain serupa juga diungkapkan oleh (Purba, 2015) bahwa profitabilitas mempengaruhi secara positif terhadap pengungkapan tanggung jawab sosial, dikarenakan korelasi profitabilitas dan penerapan CSR membentuk pantulan dan akan memberitahukan diperlukan tanggapan lingkungan agar mendapat laba. Namun, (Andriani et al., 2011) (Rofiqkoh \& Priyadi, 2016) serta (Wulandari \& Sudana, 2018)menyatakan bahwa profitabilitas tidak mempengaruhi pengungkapan tanggung jawab sosial perusahaan.

Penelitian ini menggunakan populasi penelitian yaitu perusahaan manufaktur yang terdaftar di BEI periode 2015-2017. Pemilihan periode penelitian tahun 2015-2017 bertujuan untuk memperoleh data laporan keuangan perusahaan yang terbaru dibandingkan dengan penelitian sebelumnya dan dapat memberikan informasi terkini mengenai kinerja keuangan dari suatu perusahaan sehingga menjadi lebih akurat.

Tanggung jawab Sosial Perusahaan atau Corporate Social Responsibility (selanjutnya dalam artikel akan disingkat CSR) adalah suatu konsep bahwa organisasi, khususnya (namun bukan hanya) perusahaan adalah memiliki berbagai bentuk tanggung jawab terhadap seluruh pemangku kepentingannya, yang di antaranya adalah konsumen, karyawan, pemegang saham, komunitas dan 
lingkungan dalam segala aspek operasional perusahaan yang mencakup aspek ekonomi, sosial, dan lingkungan.

Oleh karena itu, CSR berhubungan erat dengan "pembangunan berkelanjutan", di mana suatu organisasi, terutama perusahaan, dalam melaksanakan aktivitasnya harus mendasarkankeputusannya tidak semata berdasarkan dampaknya dalam aspek ekonomi, misalnya tingkat keuntungan atau deviden, melainkan juga harus menimbang dampak sosial dan lingkungan yang timbul dari keputusannya itu, baik untuk jangka pendek maupun untuk jangka yang lebih panjang.

Dengan pengertian tersebut, CSR dapat dikatakan sebagai kontribusi perusahaan terhadap tujuan pembangunan berkelanjutan dengan cara manajemen dampak (minimisasi dampak negatif dan maksimisasi dampak positif) terhadap seluruh pemangku kepentingannya CSR merupakan gagasan yang menjadikan perusahaan tidak lagi dihadapkan pada tanggung jawab yang berpijak pada single bottom line, yaitu nilai perusahaan yang direfleksikan dalam kondisi keuangannya saja. Kesadaran atas pentingnya CSR dilandasi pemikiran bahwa perusahaan tidak hanya mempunyai kewajiban ekonomi dan legal kepada pemegang saham (shareholder), tetapi juga kewajiban terhadap pihak-pihak lain yang berkepentingan (stakeholder). CSR menunjukkan tanggung jawab perusahaan harus berpijak pada triple bottom lines yaitu tanggung jawab perusahaan pada aspek sosial, lingkungan, dan keuangan.

Penelitian ini berbeda dari penelitian-penelitian sebelumnya, karena penelitian ini menggunakan tiga faktor yang mempengaruhi intensitas 
Ni Komang Ayu Trisna Dewi dan Maria Mediatrix Ratna Sari. Pengaruh ...

pengungkapan CSR yaitu ukuran perusahaan, leverage dan profitabilitas pada perusahaan manufaktur. Sektor manufaktur dipilih karena kegiatan operasinya berkaitan erat dengan eksploitasi sumber daya alam, serta memiliki dampak terkait kerusakan lingkungan sekitar wilayah lingkungan manufaktur. Perusahaan manufaktur ini juga mempunyai banyak sektor sehingga dapat memudahkan penelitian untuk melihat perusahaan dari sektor mana yang mempunyai kinerja lingkungan yang baik dan melakukan pengungkapan informasi lingkungan perusahaan. Penelitian ini sangat menarik dan penting untuk diteliti karena permasalahan lingkungan di masa yang akan datang tidak bisa diperkirakan, dan penelitian ini dapat mengetahui kinerja lingkungan setiap perusahaan serta bagaimana perusahaan dalam mengelola lingkungan dan melakukan pengungkapan informasi lingkungan.

Perusahaan yang memiliki aktivitas operasi yang besar akan mengakibatkan perusahaan mendapat sorotan dari masyarakat luas karena adanya dampak dari aktivitas perusahaan telah menyadarkan bahwa kerusakan lingkungan yang terjadi bisa dikurangi. Hal ini tidak terlepas teori legitimasi yang menyatakan bahwa organisasi atau perusahaan akan terus berlanjut keberadaannya jika masyarakat menyadari bahwa organisasi beroperasi untuk sistem nilai yang sepadan dengan sistem nilai masyarakat itu sendiri. Hubungan ukuran perusahaan terhadap CSR disclosure menurut (Andriani et al., 2011) adalah positif secara parsial. Penelitian (Gusti Ayu Dyah Indraswari, 2014) (Purba, 2015) dan (Yanti \& Budiasih, 2016)menemukan bahwa ukuran perusahaan berpengaruh terhadap CSR disclosure. Sedangkan (Pradnyani \& Sisdyani, 2015) menemukan bahwa ukuran 
perusahaan tidak mempengaruhi pengungkapan tanggung jawab sosial perusahaan yang mencerminkan bahwa klasifikasi besaran perusahaan tidak mempengaruhi luas pengungkapan tanggung jawab sosial perusahaan. Berdasarkan uraian diatas, maka hipotesis yang diajukan dalam penelitiaan ini adalah:

$\mathrm{H}_{1}$ : Ukuran perusahaan berpengaruh positif pada CSR disclosure.

Manajemen yang memiliki tingkat leverage tinggi akan meminimalisir pengungkapan CSR yang dibuat perusahaan tersebut untuk mengalihkan perhatian debtholder. Jika dilihat dari teori stakeholder, tingkat leverage perusahaan yang tinggi mengakibatkan tingkat resiko tak tertagihnya utang menjadi tinggi pula sehingga kreditor melakukan pengawasan yang ketat terhadap aktivitas perusahaan. Penelitian yang dilakukan oleh (Purba, 2015) (Yanti \& Budiasih, 2016) dan (Rofiqkoh \& Priyadi, 2016)menemukan bahwa variabel leverage berpengaruh positif terhadap pengungkapan tanggung jawab sosial perusahaan. Sedangkan (Pradnyani \& Sisdyani, 2015) dan (Wulandari \& Sudana, 2018) menemukan bahwa leverage tidak mempengaruhi pengungkapan tanggung jawab sosial perusahaan. Berdasarkan uraian tersebut, maka hipotesis yang diajukan dalam penelitiaan ini adalah:

$\mathrm{H}_{2}$ : Leverage berpengaruh negatif pada CSR disclosure

Suatu perusahaan jika tingkat profitabilitasnya tinggi akan mengungkapan informasi lebih luas sebagai salah satu upaya untuk meyakinkan pihak eksternal bahwa perusahaan sedang dalam kompetisi meyakinkan dan menonjolkan kapasitas perusahaan yang baik pada saat itu (Wardani, 2013) Dilihat dari teori stakeholder, profitabilitas perusahaan yang tinggi membuat 
manajer memiliki kesempatan lebih dalam melakukan dan mengungkapkan CSR akibat adanya alokasi dana yang lebih banyak untuk kegiatan CSR. Profitabilitas terhadap CSR disclosure menurut penelitian, (Pradnyani \& Sisdyani, 2015), (Yanti \& Budiasih, 2016) dan (Gusti Ayu Dyah Indraswari, 2014) memiliki hubungan yang positif. Pendapat lain serupa juga diungkapkan oleh (Purba, 2015)bahwa profitabilitas mempengaruhi secara positif terhadap pengungkapan tanggung jawab sosial, dikarenakan korelasi profitabilitas dan penerapan CSR membentuk pantulan dan akan memberitahukan diperlukan tanggapan lingkungan agar mendapat laba. Sedangkan (Andriani et al., 2011), (Rofiqkoh \& Priyadi, 2016) dan (Wulandari \& Sudana, 2018) menyatakan bahwa Profitabilitas tidak mempengaruhi pengungkapan tanggung jawab sosial perusahaan. Berdasarkan uraian diatas, maka hipotesis yang diajukan dalam penelitiaan ini adalah: $\mathrm{H}_{3}$ : Profitabilitas berpengaruh positif pada CSR disclosure

\section{METODE PENELITIAN}

Penelitian dilakukan di Bursa Efek Indonesia (BEI) pada periode 3 tahun 20152017. Dipilihnya BEI sebagai tempat penelitian karena BEI merupakan bursa pertama di Indonesia, yang dianggap memiliki data yang lengkap dan telah terorganisasi dengan baik.

Obyek dari penelitian ini adalah ukuran perusahaan, leverage, profitabilitas, dan kepemilikan manajemen pada CSR disclosure pada perusahaan nmanufaktur. Tahun penelitian yang digunkan dalam penelitian ini yaitu dari tahun 2015-2017. 
CSR Disclosure dihitung dengan:

$(\mathrm{CSR})=\frac{\text { Jumlah Total Pengungkapan CSR }}{\text { Skor Maksimal }}$.

Secara matematis variabel ukuran perusahaan diformulasikan yaitu:

Ukuran Perusahaan $=\log ($ total aktiva $)$

Semakin rendah rasio hutang maka semakin bagus perusahaan itu. Sebab artinya sebagian kecil aset perusahaan yang dibiayai dengan hutang. Begitu juga sebaliknya, semakin besar rasio ini berarti makin besar pula leverage perusahaan Rumus yang digunakan yaitu:

Debt to Equity Ratio $=\frac{\text { Total Liabilitas }}{\text { Total Ekwitas }} \times 100 \%$

Dalam penelitian ini, indikator yang digunakan untuk mengukur tingkat profitabilitas adalah Return of Assets (ROA). Rumus yang digunakan yaitu:

$\mathrm{ROA}=\frac{\text { Laba Bersih setelah Pajak }}{\text { rata-rata total aset }} \mathrm{X} 100 \%$

Populasi dalam penelitian ini adalah perusahaan manufaktur yang terdaftar di Bursa Efek Indonesia (BEI) tahun 2015-2017 sebanyak 145 perusahaan. Metode pengumpulan data yang digunakan dalam penelitian ini adalah nonparticipant observation, yaitu teknik pengumpulan data dengan observasi atau pengamatan dimana peneliti tidak terlibat langsung dan hanya sebagai pengamat independen.

Analisis regresi linear berganda adalah analisis yang digunakan untuk mengukur hubungan antara dua variabel atau lebih. Analisis regresi linear berganda digunakan untuk mengetahui pengaruh ukuran perusahan, leverage, dan 
profitabilitas terhadap CSR disclosure perusahaan manufaktur yang terdaftar di BEI tahun 2015-2017 melalui SPSS dengan persamaan sebagai berikut:

$$
\begin{aligned}
& \mathrm{Y}=\alpha+\beta_{1} \mathrm{X}_{1}+\beta_{2} \mathrm{X}_{2}+\beta_{3} \mathrm{X}_{3}+\varepsilon \\
& \text { Keterangan: } \\
& \mathrm{Y} \quad \text { : CSR disclosure } \\
& \alpha \quad \text { : Koefisien konstanta } \\
& \beta_{1-3}: \text { Koefisien regresi } \\
& \mathrm{X}_{1} \quad \text { : Ukuran Perusahaan } \\
& \mathrm{X}_{2} \quad \text { : Leverage } \\
& \mathrm{X}_{3} \quad \text { : Profitabilitas } \\
& \varepsilon \quad \text { : Koefisien Error }
\end{aligned}
$$

Selanjutnya pengujian hipotesis digunakan untuk mengukur ketepatan fungsi regresi sampel dalam menafsir actual secara statistic, hal ini dapat diukur dari koefisien determinasi $\left(\mathrm{R}^{2}\right)$, uji kelayakan model (uji $\mathrm{F}$ ), dan dan analisis regresi berganda.

\section{HASIL DAN PEMBAHASAN}

Perusahan manufaktur yang terdaftar di Bursa Efek Indonesia (BEI) periode 20152017 sebanyak 145 perusahaan. Perusahan yang tidak menerbitkan laporan tahunan secara lengkap berturut-turut selama periode pengamatan 2015-2017 sebanyak 14 perusahaan. Perusahaan yang mengalami kerugian sebanyak 42 perusahaan dan Perusahaan yang tidak menerbitkan laporan CSR secara berturutturut selama periode pengamatan 2015-2017 sebanyak 60 perusahaan. Sehingga jumlah sampel dalam penelitian ini adalah sebanyak 29 perusahaan manufaktur dengan total pengamatan dari tahun 2015-2017 sebanyak 87 pengamatan.

Adapun hasil analisis statistik deskriptif dari penelitian ini disajikan pada Tabel 1. 
Tabel 1.

Statistik Deskriptif Variabel Penelitian

\begin{tabular}{lccccc}
\hline & $\mathrm{N}$ & Minimum & Maximum & Mean & Std. Deviation \\
\hline Ukuran Perusahaan & 87 & 11,400 & 14,471 & 12,71546 & 0,642705 \\
Leverage & 87 & 0,154 & 2,106 & 0,76583 & 0,482448 \\
Profitabilitas & 87 & 0,006 & 0,527 & 0,10391 & 0,080349 \\
CSR & 87 & 0,088 & 0,440 & 0,24036 & 0,091427 \\
Valid N & 87 & & & &
\end{tabular}

Sumber: Data diolah, 2018

Variabel ukuran perusahaan memiliki nilai minimum sebesar 11,400 yaitu perusahaan Multi Bintang Indonesia Tbk pada tahun 2017 dan nilai maksimumnya sebesar 14,471 yaitu perusahaan Astra International Tbk pada tahun 2017. Mean untuk ukuran perusahaan adalah 12,71546 dengan nilai standar deviasinya adalah 0,642705 yang lebih kecil dari nilai rata-rata artinya ada fluktuasi yang rendah pada ukuran perusahaan yang menjadi sampel.

Variabel leverage memiliki nilai minimum sebesar 0,154 yaitu perusahaan Indocement Tunggal Prakasa Tbk pada tahun 2016 dan nilai maksimumnya sebesar 2,106 yaitu perusahaan Kedaung Setia Industrial Tbk pada tahun 2015. Mean untuk leverage adalah 0,76583 dengan nilai standar deviasinya adalah 0,482448 yang lebih kecil dari nilai rata-rata artinya artinya ada fluktuasi yang rendah pada leverage yang menjadi sampel.

Variabel profitabilitas memiliki nilai minimum sebesar 0,006 yaitu perusahaan Kedaung Setia Industrial Tbk pada tahun 2015 dan nilai maksimumnya sebesar 0,527 yaitu perusahaan Multi Bintang Indonesia Tbk pada tahun 2017. Mean untuk profitabilitas adalah 0,10391 dengan nilai standar deviasinya adalah 0,080349 yang lebih kecil dari nilai rata-rata artinya artinya ada fluktuasi yang rendah pada profitabilitas yang menjadi sampel. 
Ni Komang Ayu Trisna Dewi dan Maria Mediatrix Ratna Sari. Pengaruh ...

Variabel CSR memiliki nilai minimum sebesar 0,088 yaitu perusahaan Tempo Scan Pasific Tbk tahun 2015-2017 dan nilai maksimumnya sebesar 0,440 yaitu perusahaan Indocement Tunggal Prakasa Tbk pada tahun 2015. Mean untuk CSR adalah 0,24036 dengan nilai standar deviasinya adalah 0,091427 yang lebih kecil dari nilai rata-rata artinya artinya ada fluktuasi yang rendah pada CSR di perusahaan yang menjadi sampel.

Adapun hasil pengujian normalitas dari penelitian ini disajikan pada Tabel 2 sebagai berikut:

Tabel 2.

Hasil Uji Normalitas

\begin{tabular}{llr}
\hline & & Unstandardized Residual \\
\hline $\mathrm{N}$ & & 87 \\
Normal Parameters & Mean & 0,0000000 \\
& Std. Deviation & 0,08523006 \\
Most Extreme Differences & Absolute & 0,060 \\
& Positive & 0,060 \\
& Negative & $-0,044$ \\
Kolmogorov-Smirnov Z & & 0,564 \\
Asymp. Sig. (2-tailed) & & 0,908 \\
Durbin-Watson & & 2,170 \\
\hline Sumber: Data diolah, 2018 & &
\end{tabular}

Berdasarkan hasil uji normalitas pada Tabel 2 diperoleh nilai Sig. (2-tailed) sebesar 0,908 yang berada di atas tingkat signifikansi yang telah ditentukan, yaitu 0,05. Hasil tersebut menunjukkan bahwa data pada model regresi yang digunakan pada penelitian ini berdistribusi normal.

Berdasarkan hasil uji autokorelasi pada table 2 nilai Durbin-Watson yang dihasilkan sebesar 2,170. Oleh karena jumlah $\mathrm{n}=87$ dan $\mathrm{k}=1$, diperoleh nilai $\mathrm{d}_{\mathrm{L}}$ $=1,6280$ dan $\mathrm{d}_{\mathrm{U}}=1,67345$ sehingga $4-\mathrm{d}_{\mathrm{L}}=2,372$ dan $4-\mathrm{d}_{\mathrm{U}}=2,32655$. Oleh karena d-statistic diantara $\mathrm{d}_{\mathrm{u}}$ dan $4-\mathrm{d}_{\mathrm{u}}(1,67345<2,170<2,32655)$ atau berada 
pada daerah tidak terdapat autokorelasi, maka model regresi tidak mengandung gejala autokorelasi.

Adapun hasil pengujian multikolineritas dari penelitian ini disajikan pada Tabel 3 sebagai berikut:

Tabel 3. Hasil Uji Multikolineritas

\begin{tabular}{lllr}
\hline & \multicolumn{2}{c}{ Collinearity Statistics } \\
Model & Tolerance & VIF \\
\hline $1 \quad$ (Constant) & & 1,045 \\
& Ukuran Perusahaan & 0,957 & 1,001 \\
& Leverage & 0,999 & 1,045 \\
\hline
\end{tabular}

Sumber: Data diolah, 2018

Berdasarkan Tabel 3 di atas, dapat dilihat bahwa keempat variabel tidak ada yang memiliki koefisien tolerance lebih besar dari 10 persen dan VIF lebih besar dari 10. Hal ini berarti tidak ada gejala multikolineritas dari model regresi sehingga model tersebut layak digunakan untuk memprediksi

Adapun hasil pengujian heteroskedastisitas disajikan pada Tabel 4 sebagai berikut:

Tabel 4.

Hasil Uji Heteroskedastisitas

\begin{tabular}{|c|c|c|c|c|c|}
\hline \multirow[b]{2}{*}{ Model } & \multicolumn{2}{|c|}{ Unstandardized Coefficients } & \multicolumn{2}{|l|}{$\begin{array}{l}\text { Standardized } \\
\text { Coefficients }\end{array}$} & \multirow[b]{2}{*}{ Sig. } \\
\hline & $\mathrm{B}$ & Std. Error & Beta & $\mathrm{t}$ & \\
\hline 1 (Constant) & 0,192 & 0,116 & & 1,654 & 0,102 \\
\hline Ukuran Perusahaan & $-0,010$ & 0,009 & $-0,120$ & $-1,076$ & 0,285 \\
\hline Leverage & $-0,001$ & 0,012 & $-0,009$ & $-0,081$ & 0,936 \\
\hline Profitabilitas & $-0,016$ & 0,072 & $-0,026$ & $-0,229$ & 0,819 \\
\hline
\end{tabular}

Sumber: Data diolah, 2018

Berdasarkan hasil uji heteroskedastisitas pada Tabel 4 di atas, dapat diketahui nilai signifikansi dari variabel ukuran perusahaan sebasar 0,285 $(>0,05)$, nilai signifikansi dari variabel leverage sebesar $0,935(>0,05)$, dan nilai signifikansi dari variabel profitabilitas sebesar $0,819(>0,05)$. Oleh karena nilai 
signifikansi dari masing-masing variabel independent terhadap variabel absolute residual berada di atas 0,05 , maka dapat disimpulkan data yang digunakan pada penelitian ini bebas dari heteroskedastisitas.

Analisis regresi linear berganda menggunakan SPSS dengan hasil yang dapat dilihat pada Tabel 5 berikut.

\section{Tabel 5.}

Hasil Analisis Regresi Linear Berganda

\begin{tabular}{|c|c|c|c|c|c|}
\hline \multirow[b]{2}{*}{ Variabel } & \multicolumn{2}{|c|}{$\begin{array}{l}\text { Unstandardized } \\
\text { Coefficients }\end{array}$} & \multirow{2}{*}{$\begin{array}{c}\text { Standardized } \\
\text { Coefficients } \\
\text { Beta }\end{array}$} & \multirow[b]{2}{*}{$\mathrm{t}$} & \multirow[b]{2}{*}{ Sig. } \\
\hline & B & Std. Error & & & \\
\hline (Constant) & $-0,299$ & 0,193 & & $-1,546$ & 0,126 \\
\hline Ukuran & 0,041 & 0,015 & 0,291 & 2,782 & 0,007 \\
\hline \multicolumn{6}{|l|}{ Perusahaan } \\
\hline Leverage & $-0,022$ & 0,019 & $-0,116$ & $-1,138$ & 0,258 \\
\hline Profitabilitas & 0,284 & 0,119 & 0,249 & 2,385 & 0,019 \\
\hline $\mathrm{F}$ & $: 4,170$ & & & & \\
\hline Sig. F & $: 0,08$ & & & & \\
\hline \multicolumn{6}{|c|}{ Adjusted R Square : 0,100} \\
\hline
\end{tabular}

Dari hasil analisis regresi linear berganda pada Tabel 5 di atas, maka dapat dibuat persamaan sebagai berikut.

$$
\mathrm{CSR}=-0,299+0,041 \mathrm{X}_{1}+-0,022 \mathrm{X}_{2}+0,284 \mathrm{X}_{3}+\varepsilon
$$

Persamaan di atas menunjukkan bahwa konstanta sebesar -0,299 memiliki arti apabila ukuran perusahaan, leverage, dan profitabilitas sama dengan 0 maka nilai CSR disclosure-nya akan sebesar -0,299. Ukuran perusahaan 0,041 mempunyai arti bahwa apabila ukuran perusahaan naik 1 satuan maka menyebabkan CSR disclosure akan naik sebesar 0,041 satuan dengan asumsi variabel lainnya konstan. Leverage $-0,022$ mempunyai arti bahwa apabila leverage naik satu satuan maka menyebabkan CSR disclosure turun sebesar 0,022 satuan dengan asumsi variabel lainnya konstan. Profitabilitas 0,284 mempunyai arti bahwa apabila profitabilitas naik satu satuan maka menyebabkan 
CSR disclosure naik sebesar 0,284 satuan dengan asumsi variabel lainnya konstan.

Berdasarkan hasil uji $\mathrm{F}$ pada tabel 5 menunjukkan bahwa nilai signifikansi P value 0,008 yang lebih kecil dari $\alpha=0,05$, ini berarti model yang digunakan pada penelitian ini adalah layak. Hasil ini memberikan makna bahwa ketiga variabel independen mampu memprediksi atau menjelaskan fenomena CSR disclosure perusahaan manufaktur yang terdaftar di BEI. Hal ini berarti model dapat digunakan dapat digunakan untuk memproyeksikan karena hasil kelayakan model baik dengan nilai $\mathrm{P}$ value 0,008 .

Berdasarkan pada tabel 5 nilai adjusted $\mathrm{R}$ square sebesar 0,100 dimana memiki arti bahwa 10\% variasi perubahan CSR disclosure dapat dijelaskan oleh variabel ukuran perusahaan, leverage, dan profitabilitas sedangkan sisanya sebesar 90\% dipengaruhi oleh variabel lain diluar model regresi yang digunakan.

Tabel 5 menunjukan bahwa nilai koefisien regresi $\mathrm{X}_{1}$ atau ukuran perusahaan adalah sebesar 0,041 dengan tingkat signifikansi sebesar 0,007 lebih kecil dibandingkan dengan taraf nyata $\alpha=0,05$. Hal ini menunjukkan bahwa ukuran perusahaan berpengaruh positif terhadap CSR disclosure. Maka hipótesis yang menyatakan bahwa Ukuran Perusahaan berpengaruh positif pada CSR disclosure diterima.

Tabel 5 menunjukan bahwa nilai koefisien regresi $\mathrm{X}_{2}$ atau leverage adalah sebesar -0,022 dengan tingkat signifikansi sebesar 0,258 lebih besar dibandingkan dengan taraf nyata $\alpha=0,05$. Hal ini menunjukkan bahwa leverage 
Ni Komang Ayu Trisna Dewi dan Maria Mediatrix Ratna Sari. Pengaruh ...

tidak berpengaruh terhadap CSR disclosure. Maka hipótesis yang menyatakan bahwa Leverage berpengaruh negatif pada CSR disclosure ditolak.

Tabel 5 menunjukan bahwa nilai koefisien regresi $X_{3}$ atau profitabilitas adalah sebesar 0,284 dengan tingkat signifikansi sebesar 0,019 lebih kecil dibandingkan dengan taraf nyata $\alpha=0,05$. Hal ini menunjukkan bahwa profitabilitas berpengaruh positif terhadap CSR disclosure. Maka hipótesis yang menyatakan bahwa Profitabilitas berpengaruh positif pada CSR disclosure diterima.

Berdasarkan hasil analisis data sebelumnya, ukuran perusahaan berpengaruh positif pada CSR disclosure. Ukuran perusahaan dapat dikatakan sangat mempengaruhi terlaksananya pengungkapan sosial, hal itu dikarenakan dengan semakin besarnya ukuran perusahaan maka tanggungjawab perusahaan juga akan berpengaruh pada pengungkapan yang harus dilakukan. Hal ini disebabkan perusahaan yang memiliki aktivitas operasi yang besar akan mengakibatkan perusahaan mendapat sorotan dari masyarakat luas karena adanya dampak dari aktivitas perusahaan telah menyadarkan bahwa kerusakan lingkungan yang terjadi bisa dikurangi agar dapat dimanfaatkan oleh generasi mendatang. Oleh karena itu perusahaan akan cenderung semakin mengungkapkan tanggung jawab sosialnya untuk menunjukkan kepada masyarakat bahwa perusahaan sudah mematuhi norma yang berlaku sehingga akan mengakibatkan citra perusahaan di mata masyarakat.

Sesuai dengan teori legitimasi yang menyatakan bahwa organisasi atau perusahaan akan terus berlanjut keberadaannya jika masyarakat menyadari bahwa 
organisasi beroperasi untuk sistem nilai yang sepadan dengan sistem nilai masyarakat itu sendiri. Dengan adanya penerimaan dari masyarakat tersebut diharapkan dapat meningkatkan nilai perusahaan sehingga dapat meningkatkan laba perusahaan. Hal tersebut dapat mendorong atau membantu investor dalam melakukan pengambilan keputusan investasi.

Hasil penelitian ini konsisten dengan hasil penelitian yang dilakukan oleh Mutia dan Zuraida (2011) yang menyatakan bahwa hubungan ukuran perusahaan terhadap CSR disclosure adalah positif secara parsial. Hasil penelitian ini juga sejalan dengan hasil penelitian (Gusti Ayu Dyah Indraswari, 2014), (Purba, 2015) dan (Yanti \& Budiasih, 2016) yang menemukan bahwa ukuran perusahaan berpengaruh terhadap CSR disclosure.

Berdasarkan hasil analisis data sebelumnya leverage tidak berpengaruh pada CSR disclosure. Hal ini berarti hasil penelitian ini tidak berhasil membuktikan berlakunya teori stakeholder sebagai teori yang mendasari penelitian ini yang mengatakan bahwa manajemen yang memiliki tingkat leverage tinggi akan meminimalisir pengungkapan CSR yang dibuat perusahaan tersebut untuk mengalihkan perhatian debtholder.

Leverage dikatakan tidak berpengaruh pada pengungkapan tanggung jawab sosial karena tingkat utang suatu perusahaan tidak akan mempengaruhi luas pengungkapan tanggung jawab sosial suatu perusahaan. Hasil penelitian ini sejalan dengan hasil penelitian (Pradnyani \& Sisdyani, 2015) dan (Wulandari \& Sudana, 2018) yang menemukan bahwa leverage tidak mempengaruhi 
Ni Komang Ayu Trisna Dewi dan Maria Mediatrix Ratna Sari. Pengaruh ...

pengungkapan tanggung jawab sosial perusahaan. Ini berarti bahwa tinggi atau rendahnya leverage tidak berpengaruh pada intensitas pengungkapan CSR.

Berdasarkan hasil analisis data sebelumnya profitabilitas berpengaruh positif pada CSR disclosure diterima, karena suatu perusahaan jika tingkat profitabilitasnya tinggi akan mengungkapan informasi lebih luas sebagai salah satu upaya untuk meyakinkan pihak eksternal bahwa perusahaan sedang dalam kompetisi meyakinkan dan menonjolkan kapasitas perusahaan yang baik pada saat itu (Sudarmadji dan Suharto, 2007 dalam Wardani, 2013).

Teori stakeholder memberikan isyarat bahwa perusahaan harus memberi perhatian kepada stakeholder, karena stakeholder dapat memberikan pengaruh dan dipengaruhi oleh perusahaan berkaitan dengan aktivitas dan kebijakan yang dilaksanakan yang dalam hal ini adalah pengungkapan CSR penting karena para stakeholder perlu mengetahui dan mengevaluasi sejauh mana perusahaan melaksanakan peranannya sesuai dengan keinginan stakeholder, sehingga menuntut adanya akuntabilitas perusahaan atas kegiatan CSR yang telah dilakukannya (Riswari \& Cahyonowati, 2012)

Hasil penelitian ini konsisten dengan hasil penelitian (Pradnyani \& Sisdyani, 2015) (Yanti \& Budiasih, 2016) dan (Gusti Ayu Dyah Indraswari, 2014) yang menyatakan bahwa profitabilitas dengan CSR disclosure memiliki hubungan yang positif. Penelitian ini juga mendapatkan hasil yang serupa dengan yang diungkapkan oleh (Purba, 2015) bahwa profitabilitas mempengaruhi secara positif terhadap pengungkapan tanggung jawab sosial, dikarenakan korelasi profitabilitas 
dan penerapan CSR membentuk pantulan dan akan memberitahukan diperlukan tanggapan lingkungan agar mendapat laba.

Penelitian ini mendapatkan simpulan bahwa ukuran perusahaan dan profitabilitas berpengaruh positif pada Corporate Social Responsibility disclosure. Hal ini mendukung teori legitimasi yang menyatakan bahwa organisasi atau perusahaan akan terus berlanjut keberadaannya jika masyarakat menyadari bahwa organisasi beroperasi untuk sistem nilai yang sepadan dengan sistem nilai masyarakat itu sendiri dan teori stakeholder yang menyatakan bahwa perusahaan yang profitabilitasnya tinggi akan mengungkapan informasi lebih luas sebagai salah satu upaya untuk meyakinkan pihak eksternal bahwa perusahaan sedang dalam kompetisi meyakinkan dan menonjolkan kapasitas perusahaan yang baik pada saat itu.

Leverage pada penelitian ini tidak mempengaruhi pengungkapan Corporate Social Responsibility. Hal ini ini tidak sesuai dengan teori stakeholder yang menyatakan pengungkapan CSR penting karena para stakeholder perlu mengetahui dan mengevaluasi sejauh mana perusahaan melaksanakan peranannya sesuai dengan keinginan stakeholder, sehingga menuntut adanya akuntabilitas perusahaan atas kegiatan CSR yang telah dilakukannya (Riswari \& Cahyonowati, 2012)

Berdasarkan hasil penelitian ini, diharapkan dapat memberikan kontribusi positif, masukan dan bahan pertimbangan bagi semua pihak khususnya perusahaan dan pengguna laporan keuangan mengenai ukuran perusahaan, leverage, dan profitabilitas pada Corporate Social Responsibility disclosure 
Ni Komang Ayu Trisna Dewi dan Maria Mediatrix Ratna Sari. Pengaruh ...

perusahaan manufaktur. Bagi perusahaan, penelitian ini dapat dijadikan pertimbangan dan refrensi dalam pengambilan keputusan untuk mengungkapkan Corporate Social Responsibility.

Bagi pengguna laporan keungan atau investor, penelitian ini dapat dijadikan acuan untuk mempertimbangkan perusahaan yang melakukan pengungkapan Corporate Social Responsibility sebagai bagian yang diperhitungkan dalam pengambilan keputusan investasi karena pengungkapan Corporate Social Responsibility mencerminkan keberlanjutan suatu perusahaan.

\section{SIMPULAN}

Ukuran perusahaan berpengaruh positif pada Corporate Social Responsibility disclosure. Hal ini berarti semakin besar ukuran suatu perusahaan maka semakin luas pula pengungkapan CSR perusahaan.

Leverage tidak berpengaruh pada Corporate Social Responsibility disclosure. Hasil penelitian ini menunjukkan bahwa tinggi rendahnya leverage tidak mempengaruhi luas pengungkapan CSR perusahan.

Profitabilitas berpengaruh positif pada intensitas pengungkapan CSR. Hal ini berarti bahwa perolehan laba yang semakin besar akan memperluas pengungkapan CSR perusahaan.

Dikarenakan hasil adjusted $R$ square yang rendah dalam penelitian ini yaitu sebesar 0,100 atau hanya $10 \%$ menunjukkan bahwa masih terdapat faktor-faktor lainnya yang mempengaruhi pengungkapan Corporate Social Responsibility selain ukuran perusahaan, leverage, dan profitabilitas. Penelitian selanjutnya 
diharapkan meneliti faktor-faktor lain yang mempengaruhi pengungkapan CSR seperti jenis industri, nilai perusahaan, kepemilikan institusional, dan kepemilikan asing.

Pengungkapan CSR dalam penelitian ini diukur dengan proksi CSRDI (Corporate Social Disclosure Index) berdasarkan indikator GRI G.4 (Global Reporting Initiatives Generation) yaitu sebanyak 91 item pengungkapan. Untuk peneliti selanjutnya diiharapkan proksi CSR yang digunakan diperbaharui yaitu menggunakan GRI Standard yang merupakan pedoman terbaru.

\section{REFERENSI}

Andriani et al., (2011) Pengaruh ukuran perusahaan, profitabilitas dan ukuran dewan komisaris terhadap pengungkapan corporate social responsinility pada perusahaan manufaktur yang terdaftar di bursa efek Indonesia. Jurnal telaah \& riset akuntansi Vol. 4. 2.187-201

Arif dan Kurnia. 2008. The Analysis Of Company Characteristic Influence Toward Csr Disclosure : Empirical Evidence Of Manufacturing Companies Listed In Jsx. Vol. 12, No.1. h. 25-35.

Belkaoui, ,A dan Karpik, P,G. 1989. Determinant of the corporate decision todisclose social information.Accounting, Auditing and Accountability Journal,2(1): pp:36-51.

Bowman and Haire. 1976. A Strategy Posture Toward Corporate Social Responbility. California Management Review. Vol.18 No.2, PP. 49-58.

Braendle \& Mozghovyi, (2013). CSR - More Than Storytelling?. Journal of Governance and Regulation Vol. 9352. No. 2001. Pp. 3-80

Dahlsrud, (2008). How corporate social responsibility is defined: An analysis of 37 definitions. Corporate Social Responsibility and Environmental Management. Vol. 15. pp 1-15

Deegan, C., Rankin, \& Smith, (2009). An Examination of Corporate Social Disclosures in The ANnual reports of Indonesian Listed Companies Asia 
Pacific Centre for Environmental Accountability Journal 2009 Vol. 15, No. 3, pp 312-343.

Elsakit \& Worthington, 2014). "The Impact of Culture and Governance on Corporate Social Reporting”. International Journal of Business and Management 9, pp. 1- 15.

GRI, (2013), Global Reporting Initiative G4, Interpretations on the G4 Guidelines, issued by the Global Sustainability Standards Board, are located at the end of this document, and are to be considered by all users.," n.d.) http://www.globalreporting.org. diakses pada September 2018.

Gusti Ayu Dyah Indraswari, (2014) Pengaruh Profitabilitas, Ukuran Perusahaan, dan Kepemilikan Saham Publik Terhadap Pengungkapan CSR. E-Jurnal Akuntansi Universitas Udayana 11.1 (2015): 289-302, 11(1), 289-302.

Handoko, (2012) Manajemen Edisi 2. Yogyakarta: BPFE.

Ikatan Akuntan Indonesia, (2012). Pernyataan Standar Akuntansi Keuangan (PSAK) No. 1: Penyajian Laporan Keuangan. Jakarta: Salemba Empat.

Lucyanda, J., \& Siagian, L. G. (2012). The Influence of Company Characteristics Toward Corporate Social Responsibility Disclosure. The 2012 International Conference on Business and Management, (Viii), 601-619.

Milne \& Hackston, (1996). Some determinants of social and environmental disclosures in New Zealand companies. Accounting, Auditing \& Accountability Journal, 9(1), 77-108.

Oktariani, (2014). Pengaruh Karakteristik Perusahaan Dan Tanggung Jawab Lingkungan Pada Pengungkapan CSR Perusahaan. E-Jurnal Akuntansi Universitas Udayana (2014) 6(3) 402-418

Peloza \& Shang, (2011). How can corporate social responsibility activities create value for stakeholders? A systematic review. Journal of the Academy of Marketing Science

Pradnyani \& Sisdyani, (2015). Pengaruh Ukuran Perusahaan, Profitabilitas, Leverage Terhadap dan Ukuran Dewan KomisarisPada Pengungkapan Tanggung Jawab Sosial Perusahan. E-Jurnal Akuntasi Universitas Udayana 11.2 (2015):384-397

Purba, (2015). Pengaruh Ukuran Perusahaan Dan Leverage Terhadap Profitabilitas dan Pengungkapan Corporate Social Responsibility.E-Jurnal Manajemen Universitas Udayana, 4(8),2428-2443 
Riswari \& Cahyonowati, (2012). Pengaruh Corporate Social Responsibility Terhadap Nilai Perusahaan Dengan Corporate Governance Sebagai Variabel Moderating: Studi pada Perusahaan Publik Non Finansial yang Tercatat di Bursa efek Indonesia. Diponegoro Journal of Accounting, 1(1), 1-12.

Rofiqkoh \& Priyadi, (2016). Pengaruh Profitabilitas, Leverage dan Ukuran Perusahaan Terhadap Pengungkapan Tanggung Jawab Sosial Perusahaan. Jurnal Ilmu dan Riset Akuntansi: Volume 5, Nomor 10, Oktober 2016 ISSN: 2460-0585. Sekolah Tinggi Ilmu Ekonomi Indonesia (STIESIA) Surabaya.

Riandi, Hasan, \& Siregar, (2010). Statistik Deskriptif untuk Penelitian. Jakarta: Rajagrafindo Persada.

Swandari \& Sadikin, (2016). The Effect of Ownership Structure, Profitability, Leverage, and Firm Size on Corporate Social Responsibility (CSR). Binus Business Review

(DPR, 2007). Undang-Undang Republik Indonesia Nomor 40 Tahun 2007 Tentang Perseroan Terbatas

Veronica Siregar \& Bachtiar, (2010) Corporate social reporting: empirical evidence from Indonesia Stock Exchange. International Journal of Islamic and Middle Eastern Finance and Management Vol 3 No. 3 pp. 241-252

Vo \& Nguyen, (2014) Managerial Ownership, Leverage and Dividend Policies: Empirical Evidence from Vietnam's Listed Firms International Journal of Economics and Finance Vol. 6, No. 5, pp 274-284.

Wardani, (2013). Faktor-Faktor yang Mempengaruhi Luas Pengungkapan Sukarela. urnal Akuntansi dan Keuangan

Wulandari \& Sudana, (2018). Pengaruh Profitabilitas, Kepemilikan Asing, Kepemilikan Manajemen, dan Leverage pada Intensitas Pengungkapan Corporate Social Responsibility, E-Jurnal Akuntansi Universitas Udayana 22(2), 1445-1472

Yanti \& Budiasih, (2016). Pengaruh Profitabilitas, Leverage Dan Ukuran Perusahaan Pada Pengungkapan Corporate Social Responsibility E-Jurnal Akuntansi Universitas Udayana 17 (3), 1752-1779 